\title{
A STUDY OF THE COLIFORM, STREPTOCOCCI AND PATHOGENIC BACTERIA ALONG THE BAJA CALIFORNIA COAST
}

\section{ESTUDIO DE COLIFORMES, ESTREPTOCOCOS Y BACTERIAS PATOGENAS A LO LARGO DE LA COSTA DE BAJA CALIFORNIA}

\author{
Ma. Victoria Orozco-Borbón \\ Sergio Adolfo Sañudo-Wilhelmy \\ Instituto de Investigaciones Oceanológicas \\ Universidad Autónoma de Baja California \\ Apartado Postal 453 \\ Ensenada, Baja California \\ México
}

Orozco-Borbón, Ma. V. y Sañudo-Wilhelmy, S.A. A Study of the Colfiorm, Streptococci and Pathogenic Bacteria Along the Baja California Coast. Estudio de coliformes, estreptococos y bacterias patógenas a lo largo de la Costa de Baja California. Ciencias Marinas Vol. 14(3): 1-8, 1988.

\section{ABSTRACT}

Analises of coliforms, faecal streptococci and pathogenic bacteria were carried out surface seawater and Mytilus califomianus mussel samples collected from August to Deccmber, 1984, along the Baja California coast, México. The result showed that the bacteriological quality of the coast, in most of the localities analysed, was good.

\section{RESUMEN}

Se realizaron análisis de coliformes estreptococos fecales y bacterias patógenas en aguas superficiales y en muestras de mejillón Mytilus califomianus colectados de agosto a diciembre de 1984 a lo largo de la costa de Baja California, México. El resultado mostró que la calidad bacteriologica de la costa, en casi todas las localidades analizadas fue buena.

\section{INTRODUCTION}

Pathogenic bacteria, virus and oiner microorganisms are discharged in large numbers into the sea through sewage outfalls and pose a potential health risk to consumers of shellfish bred in adjacent waters, or to bathers at contaminated beaches.

Along the Baja California coast, the main source of bacterioiogical pollution is the sewage from the cities of Tijuana and Ensenada. Both generated approximately 24 MGD of wastewater in 1983 (Tijuana 83\%, Ensenada $17 \%$ ), which was discharged without treatment into the ocean (Orozco-Borbón, 1984).

\section{INTRODUCCION}

Bacterias patógenas, virus y otros microorganismos son descargados en gran número en el océano mediante descargas de aguas residuales y representan un riesgo potencial para la salud de personas consumidoras de moluscos bivalvos obtenidos de aguas adyacentes, o para bañistas en playas contaminadas.

A lo largo de la costa de Baja Caiifornia, las principales fuentes de contaminación bacteriológica son las descargas de aguas residuales de las ciudades de Tijuana y Ensenada. Entre ambas generaron aproximadamente $24 \mathrm{MGD}$ de aguas residuales en 
The purpose of this study was to evaluate the bacteriological quality of the water and mussels along the Northern Pacific coast of Baja California, from the United States-Mexican border south to Punta Banda, a distance of approximately 120 kilometers.

\section{MATERIALS AND METHODS}

Surface seawater samples (three per station) and mussels Mytilus califomianus (three pools of 15 organisms, each $4-6 \mathrm{~cm}$ in length) were collected from August to December, 1984, in the areas indicated in Figure 1. The water and mollusc samples were stored in sterile glass bottles and plastic bags. All samples were kept on ice until they were brought back to the laboratory. The mussels were then thoroughly washed with tap water and the byssus cut out with a scalpel. The contents (mussel meat and intervalvar liquid) were collected in a graduated cylinder and homogenized in a mixer after being diluted (1/1) with a sterile-phosphate buffer solution. The determination of the amount of bacterial contamination was based on current faecal indicators. Total faecal coliforms and faecal streptococci were evaluated by the Most Probable Number (MPN), using the standard five-tube geometrical dilution method, according to Standard Methods for Examination of Water and Wastewater (APHA, 1976). These tests were performed three times for each sample to achieve a greater precision.

Pathogenic bacteria (Salmonella and Shigella) were detected qualitatively by biochemical and serological tests according to the DIFCO handbook (DIFCO, 1978).

\section{RESULTS AND DISCUSSION}

Mean concentrations of total coliforms, faecal coliforms and faecal streptococci found in seawater and mussel samples are given in Table I. Higher concentrations of these kinds of bacteria, the presence of which indicates faecal pollution, were found nearest to the residual water discharges (Punta Bandera, Popotla and Municipal Beach). It was seen that the greater the distance from these stations, the less bacterial concentrations occurred. Previous studies, carried out during
1983 (Tijuana 83\%, Ensenada 17\%), que fueron descargadas sin ningún tratamiento en el océano (Orozco-Borbón, 1984).

El propósito de este estudio fue el de evaluar la calidad bacteriológica del agua y de los mejillones a lo largo de la costa norte-pacifico de Baja California, de la frontera entre México y los Estados Unidos hacia el sur hasta Punta Banda, una distancia de aproximadamente 120 kilómetros.

\section{MATERIALES Y METODOS}

Las muestras superficiales de agua de mar (tres por estación) y los mejillones Mytilus califomianus (tres grupos de 15 organismos, de 4 a $6 \mathrm{~cm}$ de longitud) fueron colectados de agosto a diciembre de 1984 , en las áreas indicadas en la figura 1. Las muestras de agua y de moluscos fueron guardadas en botellas de vidrio esterilizadas y en bolsas de plástico respectivamente. Todas las muestras fueron puestas en hielo hasta ser transportadas al laboratorio. Los mejillones fueron perfectamente lavados con agua corriente y el biso fue cortado con un escalpelo. El contenido (la carne del mejillón y el líquido intervalvar) fue recogido en una probeta graduada y homogeneizado en una licuadora después haber sido diluído $(1 / 1)$ con una solución buffer de fosfato estéril. La determinación de la cantidad de contaminación bacterial fue con base en los indicadores fecales presentes. Los coliformes fecales totales y los estreptococos fecales se evaluaron con el método de Número Más Probable (NMP), mediante el método estandar de dilución geométrico en cinco tubos, de acuerdo con los Métodos Estandar para Análisis de Agua y Agua Residual (APHA, 1976). Esta prueba fue repetida tres veces para cada muestra para obtener mayor presición.

Mediante pruebas bioquímicas y serológicas se detectaron cualitativamente bacterias patógenas (Salmonella y Shigella), de acuerdo con el manual DIFCO (DIFCO, 1978).

\section{RESULTADOS Y DISCUSION}

En la tabla I se muestran las concentraciones de coliformes totales, coliformes fecales 
Orozco-Borbón, Ma.V. y Sañudo-Wilhelmy, S.A., A Study...

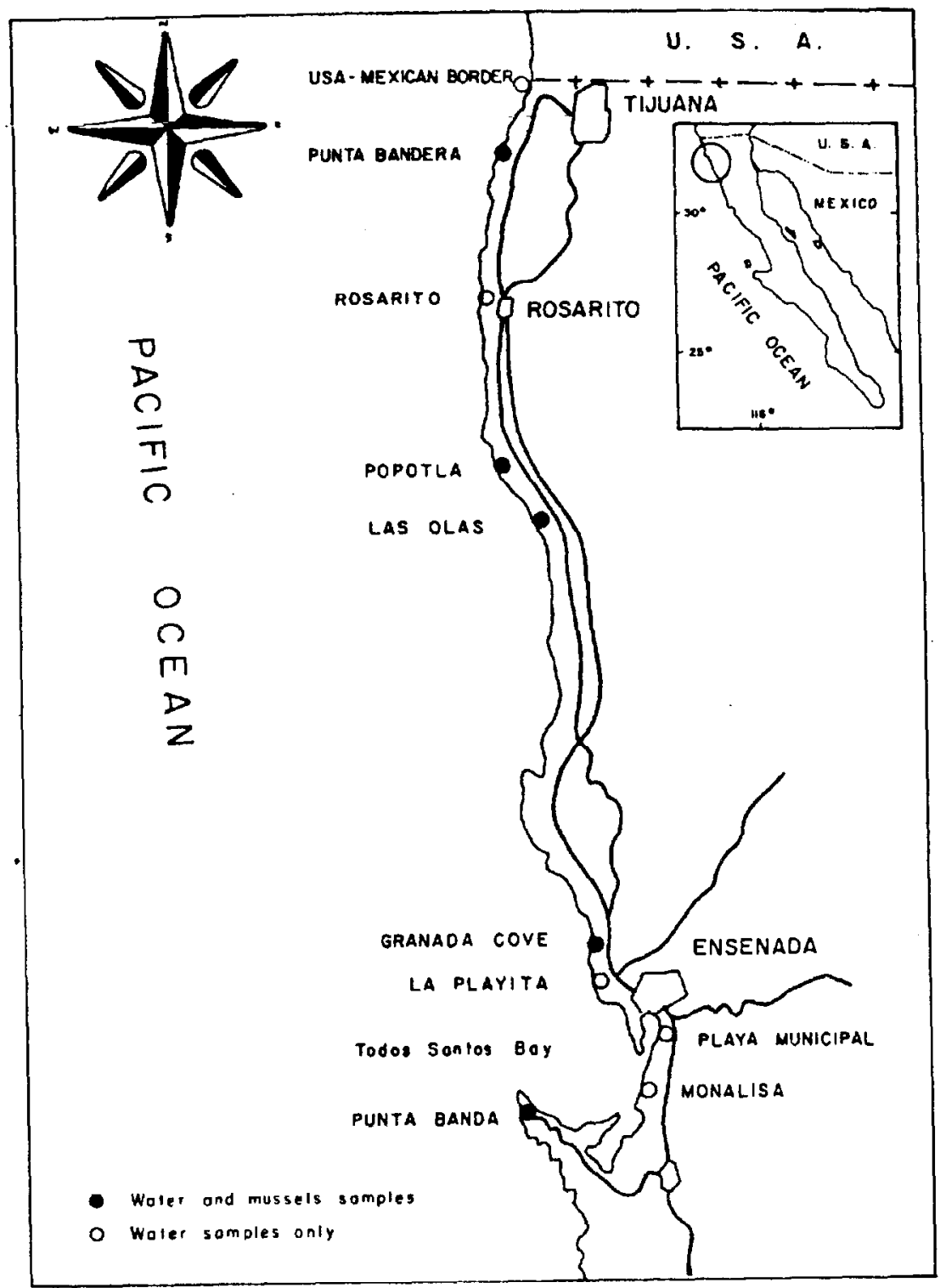

Figure 1. Localities sampled for the estimation of the bacteriological quality of the Baja California coast.

Figura 1. Localidades muestreadas para la estimación de la calidad bacteriológica de la costa de Baja California.

the period 1979-1980 (Orozco-Borbón, 1984; Sañudo-Wilhelmy et al., 1984) have also shown a similar trend in the same localities. A number of factors may account for such a tendancy; it has been noted, however, that the effect of sunlight may be the most important y estreptococos fecales de las muestras de agua de mar y de los mejillones. Las mayores concentraciones de este tipo de bacterias, cuya presencia indica contaminación fecal, fueron encontradas cerca de las descargas de aguas residuales (Punta Bandera, Popotla y la Playa 
one, controlling the decrease of faecal-indicator bacterial counts in coastal waters (Kapuscinski and Mitchell, 1983).

The greater concentrations of coliforms and streptococci were detected in summer and winter. These results agree with those reported by Sañudo-Wilhelmy et al. (1984) and Orozco-Borbón and Segovia-Zavala, (1985) who detected the maximum bacterial densities in July, August and December. The most problably explanation for this may be found in the temporary increase of the sewage due to summer tourism, and in the rain washing of soils to the sea in winter months.

Shellfish such as bivalves are particularly suited for retaining pathogenic bacteria (Pellegrino et al., 1977; Marjori et al., 1977). These organisms can filter considerable volumes of water (Jorgensen, 1960). This has a great significance for the determination of the sanity quality of coastal water when low levels of contamination are found in seawater (Plusquellec et al., 1983). The results obtained in the current study confirm the capacity of the mussels to concentrate bacteria from seawater. The values found in the molluscs at the stations of major pollution (Punta Bandera and Popotla) reached up to three orders of magnitude greater than those measured in water (Table I). Faecal streptococci and coliforms were not found in every sample analysed; these bacteria were only present in $80 \%$ of all the samples collected. This could be due to a differential absorption or a selective trapping of the two kinds of bacteria by the bivalves according to the dimension of the microorganisms (Plusquellec et al., 1983).

A high occurrence of Salmonella was only observed in the sea water samples from Popotla and Municipal Beach stations, as their location was near the raw sewage discharges. In the case of Shigella this was detected only at the Municipal Beach station. In this connection, it has been pointed out (Reasoner, 1978) that the isolation of Shigella takes place only when there are high levels of faecal pollution. Both microorganisms was isolated during the summer (August-September) and winter (December) months, and their presence were probably due to the tourism and rains, as already pointed out.
Municipal) se pudo apreciar que a mayor distancia de estas estaciones, la concentración de estas bacterias fue menor. Estudios previos realizados durante el perfodo 1979-1980 (Orozco-Borbón, 1984; Sañudo-Wilhelmy et al., 1984) mostraron una tendencia similar en las mismas localidades un gran número de factores intervienen para marcar una tendencia de este tipo; se ha notado sin embargo, que el efecto de la luz solar puede ser el más importante, controlando el decrecimiento de los indicadores de bacterias fecales en aguas costeras (Kapuscinski y Mitchell, 1983).

Las mayores concentraciones de coliformes y estreptococos fueron detectadas en verano y en invierno. Estos resultados coinciden con los reportados por Sañudo-Wilhelmy et al. (1984) y Orozco-Borbón y Segovia-Zavala (1985) que detectaron la máxima densidad de bacterias en julio, agosto y diciembre. La explicación más probable a esto puede encontrase en el incremento temporal del volumen de aguas residuales diluido al turismo veraniego, y al lavado de los suelos hacia el mar durante los meses de invierno.

Los mejillones, lo mismo que los bivalvos son particularmente aptos para retener las bacterias patógenas (Pellegrino et al., 1977; Marjori et al., 1977). Estos organismos pueden filtrar volúmenes considerables de agua (Jorgensen, 1960). Esto tiene una gran importancia para la determinación de la calidad sanitaria del agua costera cuando se encuentran niveles bajos de contaminación en el agua marina (Plusquellec et al., 1983). El resultado obtenido en el presente estudio confirma la capacidad de los mejillones para concentrar bacterias a partir del agua de mar. Los valores encontrados en las estaciones de mayor contaminación (Punta Bandera $y$ Popotla) resultaron ser de tres órdenes de magnitud mayores que los medidos en los resultados de agua (Tabla I). Los estreptococos fecales y los coliformes no se encontraron en todas las muestras analizadas; estas bacterias se presentaron solamente en el $80 \%$ de las muestras. Esto puede obedecer a una absorción diferencial o captura selectiva de estas dos clases de bacterias por los bivalvos, de acuerdo con las dimensiones de los microorganismos (Plusquellec et al., 1983). 
Orozco-Borbón, Ma.V. y Sañudo-Wilhelmy, S.A., A Study...

Table I. Three replicas of bacterial counts were carried out on each sample.

Tabla I. Se tomaron tres réplicas del conteo de bacterias en cada muestra.

\begin{tabular}{|c|c|c|c|c|c|c|c|c|}
\hline & \multicolumn{4}{|c|}{ Total Coliforms* } & \multicolumn{4}{|c|}{ Faecal Coliforms* } \\
\hline & Aug. & Sep. & Oct. & Dic. & Aug. & Sep. & Oct. & Dic. \\
\hline USA-Mexican Border & 36 & 13 & 403 & 2567 & $<2$ & 9 & 403 & 930 \\
\hline Punta Bandera & 3600 & 870 & 230 & 1533 & 360 & 230 & 230 & 750 \\
\hline Rosarito & 297 & $<2$ & 387 & 36 & 91 & $<2$ & 23 & 36 \\
\hline Popotla & 6730 & 3134 & 34 & 1733 & 5700 & 1910 & 34 & 30 \\
\hline Las Olas & 3 & 4 & $<2$ & - & $<2$ & $<2$ & $<2$ & - \\
\hline Granada Cove & 36 & 60 & 4 & 34 & 36 & 13 & $<2$ & 34 \\
\hline La Playita & 91 & 93 & 4 & 36 & 36 & 11 & $<2$ & 36 \\
\hline Playa Municipal & 1100000 & 31334 & 8700 & $25667 \quad 1$ & 11000 & 31334 & 8700 & 25667 \\
\hline Mona Lisa & 5 & $<2$ & 9 & 34 & 4 & $<2$ & $<2$ & $<2$ \\
\hline Punta Banda & 4 & $<2$ & 4 & 54 & 4 & $<2$ & $<2$ & 36 \\
\hline \multicolumn{9}{|l|}{ Mussels } \\
\hline Punta Bandera & 31334 & 330000 & 2567 & 11000 & 1500 & 870 & 417 & 1967 \\
\hline Popotla & 1700000 & 1100000 & 73 & $25667 \quad 1$ & 166000 & 140000 & 73 & 11200 \\
\hline Las Olas & 24000 & 984 & - & - & $<2$ & 28 & - & - \\
\hline Granada Cove & 11000 & 11000 & 937 & 2567 & 1500 & 127 & 417 & 1343 \\
\hline Punta Banda & 2400 & 213 & 91 & 3467 & 930 & $<2$ & $<2$ & 230 \\
\hline \multicolumn{9}{|l|}{ Continuación } \\
\hline & & \multicolumn{7}{|c|}{ Faecal streptococci* } \\
\hline & & \multicolumn{2}{|l|}{ Aug. } & \multicolumn{2}{|l|}{ Sep. } & Oct. & \multicolumn{2}{|r|}{ Dic. } \\
\hline USA-Mexican Border & & \multicolumn{2}{|l|}{36} & \multicolumn{2}{|l|}{11} & 313 & \multicolumn{2}{|r|}{420} \\
\hline Punta Bandera & & \multicolumn{2}{|l|}{$<2$} & \multicolumn{2}{|l|}{$<2$} & 887 & \multicolumn{2}{|r|}{213} \\
\hline Rosarito & & \multicolumn{2}{|l|}{$<2$} & \multicolumn{2}{|l|}{$<2$} & 257 & \multicolumn{2}{|r|}{$<2$} \\
\hline Popotla & & \multicolumn{2}{|l|}{930} & \multicolumn{2}{|l|}{930} & 213 & \multicolumn{2}{|c|}{1467} \\
\hline Las Olas & & \multicolumn{2}{|l|}{$<$} & \multicolumn{2}{|l|}{$<2$} & $<2$ & \multicolumn{2}{|r|}{-} \\
\hline Granada Cove & & \multicolumn{2}{|l|}{$<$} & \multicolumn{2}{|l|}{43} & $<2$ & \multicolumn{2}{|r|}{12} \\
\hline La Playita & & 73 & & 22 & & $<2$ & & 12 \\
\hline Playa Municipal & & 5967 & & 9367 & & 8767 & & 2133 \\
\hline Mona Lisa & & 4 & & 3 & & 55 & & $<2$ \\
\hline Punta Banda & & 3 & & $<2$ & & 23 & & $<2$ \\
\hline Mussels & & & & & & & & \\
\hline Punta Bandera & & 360 & & 11000 & & 2567 & & 11000 \\
\hline Popotla & & 673330 & & 1100000 & & 2400 & & 25667 \\
\hline Las Olas & & 36 & & 887 & & - & & - \\
\hline Granada Cove & & 297 & & 38667 & & 930 & & 283 \\
\hline Punta Banda & & 230 & & 417 & & 2400 & & 213 \\
\hline
\end{tabular}

* Three samples per station were drawn 
Table II. Percentage of samples in each station which exceeded the limits established by the Mexican Government for recreational waters $(200$ faecal coliforms $/ 100 \mathrm{ml})$. In the case of mussels the permitted levels were taken from the Food and Drug Administration, USA (230 bacteria/100gr).

Tabla II. Porcentaje de muestras en cada estación que excedieron los límites establecidos por el GobiernoMexicano para aguas de uso recreativo (200 coliformesfecales $/ 100 \mathrm{ml})$. En el caso de los mejillones los niveles permitidos fueron tomados del Food and Drug Administation, USA (230 bacterias/100gr).

\begin{tabular}{lcc}
\hline Station & Water & Mussel \\
\hline USA - Mexican Border & $50 \%$ & - \\
Punta Bandera & $100 \%$ & $100 \%$ \\
Rosarito & $0 \%$ & - \\
Popotla & $50 \%$ & $75 \%$ \\
Las Olas & $0 \%$ & $0 \%$ \\
Granada Cove & $0 \%$ & $75 \%$ \\
La Playita & $0 \%$ & - \\
Playa Municipal & $100 \%$ & - \\
Mona Lisa & $0 \%$ & - \\
Punta Banda & $0 \%$ & $25 \%$ \\
\hline
\end{tabular}

The percentage of samples in cach station which exceeded the limits established by the Mexican Government for recreational waters ( 200 faecal coliforms $/ 100 \mathrm{ml}$ ), is shown in Table II. The samples from Punta Bandera and Municipal Beach stations always exceeded the permitted values, while at the USA.-Mexican border and Popotla stations only $50 \%$ of the samples exceeded such values. The remaining stations were found relativcly clcan. The Mexican Legislation does not consider maximum values of bacteria in molluscs. We therefore performed a comparison with the values established by the US Government ( 230 faecal coliforms $/ 100 \mathrm{gr}$ ). Table II shows that all the samples from Punta Bandera and 75\% of the samples from Popotla and Granada Cove stations exceeded this limit. It is obvious that the molluses from these locations are unsuitable for human consumption. At the Punta Banda station, the coliform concentration exceeded the limit only in August. This is not surprising, as Todos Santos Bay is polluted during the summer months (Sañudo-Wilhelmy et al., 1984) and during this period a current flows from the central part of the Bay to Punta San Miguel in the North and
Solamente en las muestras de agua de Popotla y la Playa Municipal se observó una gran ocurrencia de Salmonella, dado que su localización se encuentra cercana a las descargas de aguas residuales. En el caso de Shigella, solamente fue detectada en la estación de la PLaya Municipal. Se ha senelado (Reasoner, 1978) que el asilamiento de Shigella se logra solamente cuando existen altos niveles de contaminación fecal. Ambos organismos fueron aislados durante el verano (agosto-septiembre) y el invierno (diciembre) y su presencia se debe probablemente al turismo y a las lluvias, como ya se señaló anteriormente.

El porcentaje de las muestras que excedió los límites establecidos por el Gobierno Mexicano para aguas de uso recreativa (200 coliformes fecales $/ 100 \mathrm{ml}$ ) se muestra en la tabla II. Las muestras de Punta Bandera y la Playa Municipal exceden estos límites permitidos, mientras que en las estaciones de la frontera México-EUAy en Popotla, solamente el $50 \%$ de las muestras lo exceden. Las estaciones restantes fueron encontradas relativamente limpias. La Legislación Mexicana no considera valores máximos de bacterias para 
to Punta Banda in the South (Argote, et al., 1976). The mussel samples taken from Las Olas stations were always within the limits. The bacteriological pollution problems along the Baja California coast have been greatly exaggerated. At the U.S.A-Mexican border station, pathogenic bacteria were not detected throughout this study. Heavy pollution occurred only in limited areas. There are many other beaches which are not affected by sewage outfalls where the bacteriological quality was excellent.

\section{LTERATURA CITADA}

APHA, AWWA, WPCF, (1975) Standard Methods for the Examination of Water and Wastewater. 14ed. APHA, Washington, DC, p. 1193.

Argote, M.L., Amador, A. y Morales, C. (1976) Distribución de los parámetros salinidad, temperatura y tendencia de la circulación en la Bahía de Todos Santos, BC. En: Memoriade la Primera Reunión de los Centros de Investigación de Baja California y la Institución Scripps de Oceanografła, CICESE (ed.), Ensenada, BC., p. 3-30.

DIFCO (1978) Manual de Bacteriología. DIFCO (ed). Valdemoro, Madrid. 395pp.

Jorgensen, C.B. (1960) Efficiency of Particle Retention and Rate of Water Transport in Uundisturbed Lamellibranchs. J. Cons. Perm. Int. Explor. Mer. 26: 96-116.

Kapuscinski, R.R. and Mitchell, R. (1983) Sunlight-Induced Mortality of Virus and Escherichia Coli in Coastal. Seawater Environ. Sci. Tech. 17: 5-10.

Marjori, L., Campello, C. and Crevatin, E. (1975) Salmonella pollution of the Gulf of Trieste. Rev. Int. Oceanogr. Med. 47: 181-191.

Orozco-Borbón, M.V. (1984) Evaluación de la calidad bacteriológica del agua de mar y Mytilus califomianus en la zona costera noroccidental de Baja California, México. Tesis de Licenciatura en Oceanolog fa, Escuela Superior de Ciencias Marinas, UABC, 62pp. moluscos. Realizamos una comparación con los valores establecidos por el Gobierno de EUA (230 coliformes fecales/100gr).

La tabla II muestra que todas las muestras de Punta Bandera y el $75 \%$ de las muestras de Popotla y Granada Cove excedieron este límite. Es evidente que los moluscos provenientes de estos puntos no son útiles para el consumo humano. En la estación de Punta Banda la concentración de coliformes excedió el límite solamente en agosto. Este no es sorprendente dado que la Bahfa de Todos Santos es contaminada durante los meses de verano Sañudo-Wilhelmy et al., 1984) y durante este período hay una corriente que fluye de la parte central de la $\mathrm{Ba}$ hía hacia Punta San Miguel en el norte y hacia Punta Banda en el sur (Argote et al., 1976). Las muestras de mejillones tomadas en la estación Las Olas resultaron siempre bajo el límite. Los problemas de contaminación bacteriológica a lo largo de las costas de Baja California han sido grandemente exagerados. A la altura de la Frontera México-EUA no se detectaron bacterias patógenas en este trabajo. La contaminación de importancia ocurre solamente en áreas limitadas. Existen muchas otras playas que no están afectadas por descargas de aguas residuales y que resultaron con una calidad bacteriológica excelente. Pou.

Trabajo traducido al Español por Sergio

Orozco-Borbón, M.V. y Segovia-Zavala, J.A. (1986) Calidad bacteriológica del agua de mar en la zona costera noroccidental de Baja California, México. Ciencias Marinas 12(1): 7-17.

Pellegrino, C., Carli, A., Cevasco, P. and Scasso, M.J. (1977) The Mytilus galloprovincialis Lamarck as an Accumulator and Indicator of Telluric Microorganisms in the Sea Water. Rev. Int. Oceanogr. Med. 47: 155-160.

Plusquellec, A., Beucher, M. and LeGal, Y. (1983) Enumeration of the Bacterial Contamination of Bivalves in Monitoring the Marine Bacterial Pollution. Mar. Pollut. Bull 14: 260-263. 
Orozco-Borbón, Ma.V. y Sañudo-Wilhelmy, S.A., A Study...

Reasoner, D.J. (1978) Microbiology: Detection of Bacterial Pathogeneus and their Occurrence. J. Water Pollut. Control Fed. 50: 1382-1395.
Sañudo-Wilhelmy, SAA., Morales-Yañez, A. y Vargas-Flores, J.A. (1984) Contaminación fecal en la Bahra de Ensenada, Baja California, México. Ciencias Marinas 10: 7-17. 